https://doi.org/10.15407/scine16.06.028

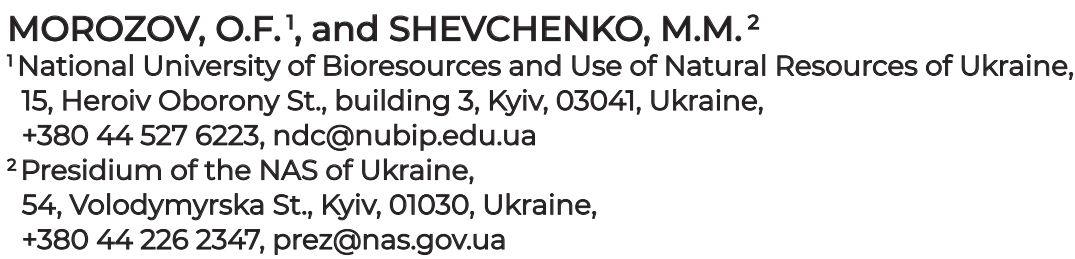

\title{
SUBJECT-OBJECT RELATIONS AS "WHOLE GENERAL EFFECT" IN MANAGEMENT
}

Bcmyn. The socio-economic structure and the structure of economic production in Ukraine are get increasingly subjected to the consumption of goods and services.

Problem Statement. In the outlined conditions, the problem is that in most cases, the economy has been already controlling the human being, not vice versa.

Purpose. The development of a systematic approach to the problem of revealing the essence of the relationship between the "subject" of economic space management, the human being, and the "object" of management, the economic space, in order to find ways to return to human-centered socio-economic structure of the country.

Materials and Methods. For the first time, a new concept of "social effect" has been introduced. It is an ana$\log$ of the well-known lexicographic effect proposed at the beginning of the 21tt century by Full Member of the NAS of Ukraine V. Shirokov, which may be regarded as a phenomenological framework of the theory of complexity and the corresponding specific theory of economic information, on the one hand. On the other hand, the complexity theory, the Kolmogorov in-formation, and the Levenheim-Skolem theorem may be considered formal correlates of the lexicographic effects in economic systems.

Results. This approach is considered system-creating to describe the holistic processes of relations of economic systems of five levels with the phenomenal property of self-compensation of complexity. The separation of structural, substantive, and subjective properties, as well as the relationships between them gives the analyzed economic reality the property of being a system.

Conclusions. Based on the above assumptions and general theoretical and informational ideas about socioeconomic systems of five levels as formal correlates of the lexicographic effect, it has been proposed to coordinatize and to unify information in the economic space of these management systems as a basis for establishing the "source - form - content" equilibrium in accordance with the rule of "common goals".

Keywords : management, economy, object, subject, system, goals, form, and content.

Modern Ukrainian society has gradually become a consumer society. In the absence of material prosperity, the Ukrainian moral and psychological climate has generated in society a so high desire for consumption that people want much more than they may afford.

Citation: Morozov, O.F., and Shevchenko, M.M. Subject - Object Relations as "Whole General Effect" in Management. Sci. innov. 2020. V. 16, no. 6. P. 28-35. https://doi.org/10.15407/scine16.06.028 
The socio-economic and production structure is increasingly subject to the consumption of goods and services. Today, the economy governs people, rather than the other way round. The thirst for possession of material goods has almost completely captured the entire consciousness of the majority of the able-bodied population of Ukraine replacing the intangible, spiritual, and creative values. The present-day postmodern era, therefore, is the culmination of the recognition of "material" (money) as the highest value with the maximum desire of people to individualize and to distance themselves from society. People have become skeptical, distrustful with regards to social phenomena.

The object-centric concept of human economic behavior has reached its peak in the course of its evolution, with "ratio" becoming the highest achievement of its evolution. Surprisingly, the economy plays a dominant role, it has become a "subject", while the human being has changed into an "object" of its "management" aiming at ensuring the self-sufficient existence of economy. Such evolution has turned the human being into a modern "slave" of the golden calf.

However, the spirit, like faith, continues to play the role of a functional framework of conscious, intelligent behavior. In the subject-centered economy, the human being continues to be the origin and generator of everything, as he/she focuses his/her spiritual efforts on perceiving the world from the standpoint of the subject whose consciousness has no clear boundaries but relies on intuition rather than on knowledge.

In fact, the concept of subject-centered economy is not natural, it is a temporary historical phenomenon that is erroneous and artificial. This is the main cause of the general crisis of modern civilization, which is a consequence of the postmodernism philosophy that has formed the ultimate and, as the world economists mistakenly believe, irreversible individualization of society. Such conclusions are based on numerous reasons, in particular: long stay in the virtual world, the emergence of the Internet as the quintessence of postmoder- nism, the creation and development of circumstances in which the human being no longer needs a "collective" method of production and coexistence, preferring mostly individual attitude to life as object of temporary stay in this world.

The urgent task of the current stage of economic theories is to find ways at a higher whorl of the civilizational evolution spiral in order to enable the human being to return to the role of subject of managing political and socio-economic development of the country.

Deep information principles of subjectivity in the structure of economic space from the standpoint of lexicographic effect, which are discovered at the beginning of the $21^{\text {st }}$ century by Full Member of the NAS of Ukraine V. Shirokov have been considered in [1, 2]. On the one hand, this effect can be considered a methodological and phenomenological framework of the complexity theory and the corresponding certain theory of economic information [3]. On the other hand, on the contrary, the complexity theory, the Kolmogorov information, and the Löwenheim-Skolem theorem can be interpreted as formal correlates of the lexicographic effect in economic systems and as a basis for establishing a balance of information on the "subject - object" relationship in the economic space and for coordinating and unifying the management of economic systems of five levels. Based on this approach to understanding and interpreting the nature of the balance "source - form - content" of economic information [4], it is possible to use both observable and unobservable data more deeply and reliably. This approach to the sources, form, and content of sets of input measurable and latent data is the information framework for the actual search and study of the balance of information on the "subject - object" relationship in the economic space, which is the purpose of this research.

Below, there is described a way to return the situation in the economy of Ukraine to its natural state and to put in the proper way the conditions of the "subject - object" relationship in the structure of the economic space. 
In this research, the human being acts as a "subject" of economic management, with economic space being an "object" of human management. Thus, in such conditions, the human being as a "subject" of management has a dualistic nature. According to the theory of categories [5], this dualism can be represented in the form of a commutative diagram (for example, the Set category, with all sets as objects, and the functor arrows representing all functions between the sets). According to Set (1) the human being as a subject of management has a "mechanism" $S_{F}$ for direct (perceptual-sensory, i.e. reflecting the shape of things) comprehension of economic space as an objective reality $D$ and has a creative "apparatus" for "intellectual" processing of received information by interpretation of its "content" $H 1$ (for example, smart brain). In addition, it may have some additional "interface" between these two methods of information processing, which in the category $\operatorname{Set}(1)$ is defined by the element $H 2$ :

$$
S_{F} \stackrel{F(D)}{\longrightarrow} H 1+H 2 \stackrel{C(D)}{\longrightarrow} H D,
$$

Category (1) cannot be understood without the introduction of a subjective principle that is abstracted from the fundamental, immanent properties of the matter. The Set (1) category establishes the existence, while $D$ is first introduced as given. It should be noted that despite the fact that the information characteristics (properties associated with the complexity of the object) manifest themselves (are updated, explained) in the process of "subject - object" interaction, this does not happen unless these properties in "convolute" form are hidden in the structures of both the subject and the object.

Thus, in accordance with the model of the "subject - object" relationship in the form of category Set (1) proposed in [6], the "subjectivity" of human being is not only an external feature with respect to economic space as an "object", but also the internal ability of the object to "reflect" its immanent properties. The stated understanding of the system of correct relations of the human being as a "subject" of management to economic (political) space structured in a certain way as an "object" of management has a close connection $S$ with quantum principles of perception and description of the reality, according to which the fundamental characteristics of the object is its state that theoretically, i.e. in the process of scientific description, takes shape of the main conceptual object.

Given the above, it is expedient to give some general scientific considerations regarding the concept of system states. In our opinion, this concept used in many natural, socio-humanitarian, and technical disciplines has been developed in the best way, both theoretically and practically, in quantum mechanics where it is a fundamental principle. According to the canonical doctrine of quantum mechanics, at each instant of time, the system is in a certain definite state. The state of the system is formalized as a solution of the Schrödinger equation for this system. Since the latter is a differential equation in partial derivatives, many its solutions that are identified with the states of this system, form an infinite Hilbert space. Therefore, the number of the states of a quantum mechanical system is theoretically infinite.

The state of economic space, as well as the quantum system, may have the most complete description in theory and be determined by probabilistic interpretation, but the "state" of economic space (crisis, balanced, etc.) is not a directly observable quantity, but a latent characteristic whose parameters are estimated according to selected models.

It is well known that the observable quantities in quantum mechanics are determined by Hermitian operators acting in the Hilbert space, with the possible values of the observable quantities calculated as matrix elements of these operators in the state space. However, in some other theories, the state of the system is an observable quantity. For example, in classical mechanics, the state of a material point is given by the coordinate-momentum pair at a certain instance:

$$
(x(t), p(t)),
$$


With each of them observed both separately and together. In quantum mechanics, there is a fundamental limitation on the simultaneous measurement of coordinates and momentum, which is stated by the Heisenberg uncertainty principle.

Hence, the concept and the status of the observed quantity are non-invariant and defined differently across natural science (and other) theories. This gives a certain "spiciness" to the use of the concept of "state" of systems $D$ (see category Set (1) in the theory of economic calculus, which, in its current form, generally ignores the phenomenon of observability). For the purpose of economic theory, one can operate only with the observed quantities, but this issue is not simple. It started to be widely discussed in physics at the origins of quantum theory and has not lost relevance to the present day. The achievements of this field of theoretical knowledge contain general methodological experience and guidance, which may and shall be mastered by any science that has ambitions for a theoretical understanding of the nature of the things.

The first and most important is that most likely, according to the model of the "subject - object" relationship in the form of category Set (1), as proposed in this research, in order to characterize the states of objects $D$, both observable $S_{F}$ and directly unobservable values of $H=H 1+H 2$ are used.

So, the state of economic space objects D is more or less clear, whereas the state of the subject requires additional consideration within the framework of the proposed research. Moreover, according to most researchers, it is impossible to build a theory with the use of only observable quantities. However, at the same time, it is clear that without the observable quantities neither scientific theory nor science in general is possible at all. Observable and unobservable quantities shall have different logical and ontological status, but, as far as we know, no general theory of this issue has been developed in detail yet.

Proceeding from the above, the relationship between observable $S_{F}$ and directly unobservable values $H$ of the state of economic space objects $D$ may be interpreted as follows: they are respectively "formal" and "informative" side of the object of management, and therefore can be formalized as registered and interpretive parts of some hypothetical lexicographic system of the "subject - object" relationship model in the form of category Set (1).

When applied to objects of economic space, this interpretation can be detailed in the aspect that the state of any element that is an object of economic space $D$ involves decomposing the formal component of category Set (1) into the observable component $S_{F}$, achievable for subject of direct perception, digital data or graphics) and the informative component determined directly by unobservable values of $H$.

$H=H 1+H 2$ is a set of "all contexts of intellectual evaluation" of the object of the economic space $D$, in which any unit of the economic system can operate. It is this circumstance that makes this part of the state directly unobservable.

In this context, we shall pay attention to the logical and psychological foundations of the phenomenon of observation. It should be noted that such a philosophical statement as Mach's principle, according to which sensory impressions are organized in human thinking in a way that ensures the most economical arrangement of these impressions into stable complexes. In this part, a significant compensation of complexity is possible due to the maximum consideration of coincidence, i.e. "commonality" of the goals of the system elements, since the specific individual goals of these elements are set by management in the element $H=H 1+H 2$ in Set (1).

Albert Einstein considered this principle too banal to play the role of a universal epistemological law, but he could emphasize the special role of the category Set (1) in the ontological-logicalpsychological development of the management process. From this point of view, the component $H$ is not only a way of fixing sensory complexes, but also a reflection of what exists (or even may exist) outside these complexes and without con- 
nection with them. In our opinion, Einstein's possible remark (and he was very sensitive to the philosophy of knowledge) about the role of Set (1) is not accidental. It would emphasize our thesis about the universality and dualism of the material and intangible composition of cultural and information processes at all levels of reality.

The following remarks concern the discussion of the criterion of simplicity, when Set (1) is not necessarily connected with the Mach principle. The simplicity of Set (1) becomes aesthetically attractive for most managers: the natural simplicity and beauty of the mathematical scheme of the category Set (1) has a significant convincing force for them. It is worth mentioning that the very possibility of the existence of such a phenomenon as "management" is a consequence of the human being property to be a subject in the "subject object" relations in the economic space.

It should be pointed out that at the time of creation of quantum theory, the concept of simplicity (like the antonymous and related concept of complexity) was commonly used, while the theory of complexity had not yet been formulated. It appeared as late as in the 1950s. The relationship between the characteristics of objects and their descriptions (and therefore their simplicity!) and information has also not been understood, and no quantitative measures have been known to estimate these quantities and their relationships. This concerns the concept of complexity developed by A. Kolmogorov and other scholars, as well as its connections with information aspects.

Hence, all the above mentioned is ready to be implemented in economic theory of management. The minimalistic description of the object under study, which according to A. Kolmogorov, is an objective measure of the amount of description of reality and actually with the concept of information and its quantitative measure has a deep connection with the criterion of simplicity and beauty of scientific theory of information about this object, encourages scholars (at least, at the subconscious level) to find descriptions of this type, although it neither indicates ways and nor gives any guidance, because it belongs to the class of algorithmically unsolvable problems. However, the lack of ways and guidance does not deny the objectivity of the existence of minimalistic description. It is only an evidence that there is no formula or algorithm for obtaining new scientific truths. And when such a description is found, it obviously should look like the simplest one.

Thus, the criterion of simplicity (or beauty) of possible elements of scientific theory, in our opinion, is follows from the general nature of information and corresponds to the formal definition of the measure of its quantity, according to A. Kolmogorov, rather than a consequence of the principle of economy of thought (described by Einstein as "suspiciously commercial" and having only a very indirect relation to the subject of matter, since here we are talking about the fundamental information property of objectively existing things, rather than about the feature of thinking as a subjective process).

Indeed, when a description of an economic object (process, system, etc.) that is managed in a way that most adequately corresponds to its essence is obtained, this description shall be minimal, as it contains only essential information about the object managed by the entity and does not contain any description of random, insignificant details that "contaminate" the essential with excessive elements.

Leader, politician or top manager as a subject of management instinctively seeks to obtain such a description of the objects of economic space, which, in our opinion, is consistent with the Kolmogorov definition of information measure based on the minimum description. This, in our opinion, explains the psychological confidence that a politician or a top manager feels when he/she gets a simple (beautiful!) practical answer on how to effectively manage socio-economic systems: strategically, tactically, quickly, and even operationally.

Simple solutions to complex problems appear, in particular, because of a quite accessible formalism of complexity theory, which is both transparent and deep. It should be perceived ontological- 
ly as an objective property of things. One of the new elements of complexity theory is the concept of limit of order", which was proposed in [7]. One of the non-trivial manifestations of this feature is that the complexity of the outlined problem is not equal to the sum of the complexities of the essences of the constituent problems.

That is, complexity is not an additive function of any economic system that exists in an oriented and coordinated economic space. In other words, if there is some economic system consisting of other, "smaller" economic subsystems that are its constituents, i.e.:

$$
D=\cup D_{i},
$$

where $\cup$ denotes "affiliation"; $D$ is economic system; $D_{i}$ are components of this economic system:

$$
K(D) \neq \Sigma K\left(D_{i}\right),
$$

where $K(D)$ is the quantitative measure of the complexity of the system $D ; K\left(D_{i}\right)$ respectively, the quantitative parameters of the complexity of its constituents $D_{i}$ (usually, $K(D)<\Sigma K\left(D_{i}\right)$ ). This, of course, applies to individual $K\left(D_{i}\right)$ and to their constituents.

In the process of creation, operation, and interaction of economic systems of five levels [4] there is such a phenomenon that is considered "self-compensation of complexity". The meaning of this phenomenon is as follows.

The nature of the interaction of constituents forming a certain unity (integrity) that is identified as a composite object, is such that in the "bound" state they show only a certain part of its complete, "immanent" complexity. The need for such behavior can be interpreted as a property that provides a fundamental opportunity to disclose the essence of "manifested" being and, perhaps, even its existence. Otherwise, the complexity of any object would be actually infinite (potentially it is), and so the complexity of individual components is allegedly "self-compensated" while forming the whole according to the rule of "common goals".

That is, it can be stated that the potential complexity of any thing is infinite, because today it is impossible to see the limits of the divisibility of matter, and each lower structural level has its non-zero complexity. However, all kinds of complexity of components are not displayed together at the same time, they manifest themselves level by level. Therefore, in each case, the complexity is subject to "renormalization," similarly to quantum electrodynamics, where for eliminating differences it is necessary to use the procedure of "deduction of infinity". A clear example of selfcompensation of complexity gives us a structured, focused, coordinated economic space.

Thus, a measure of the complexity of a particular economic system can be considered its simplex representation that takes into account the effects of the existence of "symmetry groups", including the plurality of topological features. In this case, set of sets, sets, etc. (in a specific context) in the economic space functions have power only in a certain sense: in one or in several "blended" possible values of SUBSTANTIVE and NON-SUBSTANTIVE capacity of economic systems [4], and therefore, the measure of its complexity in a particular context is determined only by part of the power of systems at a certain level. Moreover, in some cases, the capacity of economic systems, for example, [UAH / s], can make up only a tenth or even a hundredth part of the full complexity of the economic space [7 -9].

Thus, the complexity of the total capacity may be less than the total complexity of the capacity of a single lower-level economic system that is part of a higher-level economic system. The structure of being in the economic space is paradoxical! The phenomenological approach suggests that complex economic systems actually consist of even more complex ones. In this context, "more" is less than "less".

There appears the self-compensation of the complexity of economic space that is the object of human management, which, according to our logic, now confidently becomes the subject of management of such economic space, in which complexity is self-compensated by the rule of "common goals". 
In our opinion, non-trivial confirmation of this thesis is the known effect that has ontological, epistemological, and psychological dimensions. It concerns the complexity of scientific theories: for example, the theory of atoms is not simpler than the theory of molecules, the theory of nuclei is not simpler than the theory of atoms, the theory of elementary particles is not simpler than the theory of the nucleus, etc. In economics, the complexity of, for example, national budget is simpler than the complexity of regional budgets and so on.

Proceeding from the above, the principle of "reductionism", according to which complex things should consist of simpler ones, seems to be dubious rather than obvious, which encourages the revision of the fundamentals of standard systems analysis.

At this level, it has been proposed within the principles of "holism" to take into account the effects described by the theory of complexity in such a way that the latter gets the features and status of economic-social-natural and general scientific metaphor, not just mathematical doctrine.

Thus, the above develops an understanding of the approach to systems, based on the relationship between the "subject" of economic space management, the human being, and the "object" of management, the economic space. This relationship is considered to be system-creating for economic systems of five levels (quantum-, micromeso-, macro-, and mega- economic levels of the subject of management levels) with the phenomenal property of self-compensation of complexity. It is the selection of structural, substantial, and subjective properties of these levels, as well as the holistic connections between them, which adds the property of "being a system" to the analyzed economic reality. Based on these assumptions and general theoretical and information ideas about socio-economic systems, the research has proposed for the first time a new concept that is analog of the known lexicographic effect introduced at the beginning of the $21^{\text {st }}$ century by V. Shirokov, Full Member of the NAS of Ukraine. On the one hand, it may be considered phenomenological framework of the theory of complexity and the corresponding certain theory of economic information. On the other hand, on the contrary, the theory of complexity, Kolmogorov information, and Levenheim-Skolem theorem are naturally considered formal correlates of lexicographic effect in economic systems and a basis for establishing the "source - form - content" balance of information in economic space and for coordinating and unifying the economic systems of five levels based on "common goals".

This new effect has previously been proposed as "whole general effect" that arises in the "core" of the "subject - object" relationship in the structure of economic space as an effect of self-compensation of the complexity of economic systems.

The authors express their sincere gratitude to a dear friend, outstanding researcher, Full Member of the NAS of Ukraine Volodymyr Shirokov, author of numerous unique research works, for deep ideas and consultations, research results, and publications provided by him, which have formed the framework for applying his ideas to the economic sphere and to this research.

\section{REFERENCES}

1. Shirokov, V. A. (1998). Information theory of lexicogra] items. Kyiv: Dovira.

2. Shirokov, V. A. (2015). Linguistics and systems approach. Bıonics of intelligence: scientific and technical. Magazine, 1(84), $26-57$.

3. Kolmogorov, A. N. (1987). Information theory and algorithm theory. Moscow: Nauka.

4. Morozov, O. F. (2014). Methodology for measuring intangible assets of innovation systems of five levels. Economist, 9 , $35-38$.

5. McLain, S. (2004). Categories for working mathematicians (Ed. V.A. Artamonov). Moscow: FIZMATLIT.

6. Morozov, O. F. (2016). The objectivity of the "reduction" of human consciousness into material economic values. Economist, 1, 2-7. 
7. Morozov, O. F., Shevchenko, M. M. (2017). Some special elements of management theories on the management of socioeconomic systems according to the rules of "common goals". Economist, 10, 19-23.

8. Morozov, O. F. (2016). Economics, time and geometry. Inventor and innovator, 2, 8-11.

9. Morozov, O. F. (2016). Economics, time and geometry. Inventor and innovator, 3, 4-8.

Received 10.09.19

Revised 24.12.19

Accepted 17.02.20

О.Ф. Морозов ${ }^{1}$, М.М. Шевченко ${ }^{2}$

${ }^{1}$ Національний університет біоресурсів і природокористування України, вул. Героїв Оборони, 15, Київ, 03041, Україна,

+380445276223, ndc@nubip.edu.ua

${ }^{2}$ Президія Національної академії наук України, вул. Володимирська, 54, Київ, 01030, Україна, +380 44226 2347, prez@nas.gov.ua

ВІДНОСИНИ СУБ’СКТ-ОБ’ЄКТ

ЯК «ЦІЛЕСПІЛЬНИЙ ЕФЕКТ» МЕНЕДЖМЕНТУ

Вступ. Соціально-економічний устрій та структура економічного виробництва в Україні стають все більше підпорядкованими споживанню товарів і послуг.

Проблематика. В окреслених умовах проблемою є те, що у більшості випадків вже економіка керує людиною, а не навпаки.

Мета. Розроблення системного підходу до проблеми розкриття сутності взаємовідносин між «суб’єктом» управління економічним простором - людиною та «об'єктом» управління - економічним простором для пошуку шляхів повернення до людиноцентризму соціально-економічного устрою країни.

Матеріали й методи. Вперше введено нове поняття «цілеспільний ефект» - аналог відомого лексикографічного ефекту, запропонованого на початку XXI століття академіком НАН України В. Широковим, який можна розглядати, з одного боку, як феноменологічну основу теорії складності й відповідної певної теорії економічної інформації, а з іншого боку, навпаки, теорію складності, колмогорівську інформацію і теорему Левенгейма-Сколема природно розглядати як формальні кореляти лексикографічного ефекту в економічних системах.

Результати. Таке відношення автори покладають як системотворче для опису холістичних процесів відносин економічних систем п'яти рівнів із феноменальною властивістю самокомпенсації складності. Виділення структурних, субстанціальних і суб'єктних властивостей, а також зв'язків між ними надає аналізованій економічній реальності властивість «бути системою».

Висновки. Виходячи з викладених припущень і загальних теоретико-інформаційних уявлень щодо соціальноекономічних систем п'яти рівнів, як формальні кореляти лексикографічного ефекту запропоновано в таких економічних системах як базис для встановлення балансу «джерело - форма - зміст» координатизацію та уніформізацію інформації в економічному просторі цих систем менеджменту здійснювати за правилом «спільних цілей».

Ключові слова: менеджмент, економіка, об’єкт, суб’єкт, система, цілі, форма, зміст. 